（東京篮國大學工學部應用化學科無機工業化學研究窒）（昭和四年二月一四日受理）

\title{
セメント中の不溶解殘渣の成分に就て
}

\author{
工學士 永井 彰 一 郎
}

緒式

暴に著者は別報「セメントの聯結硬化の强度と化學成分」第二報及び「ポルトランドセメントの水硬成分に 關する新比率に就て」第二㓑等に於てセメントの主要水硬成分中の石灰と珪酸との化合比として不洃珪酸化合

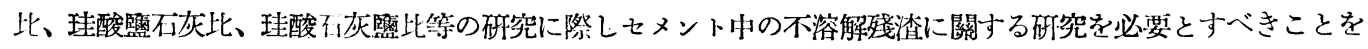
認めたり

セメントの化學成分の分析に於て不溶解残洫の定量は極めて煩雜、团難なる操作に依るものなり而して普通 のポルトランドセメント系のセメントに於ては其の製造法にして順調なる時は此の不溶解殘渣の量は桖めて少 量にして多くの場合 0.3〜0.5 \%を出でざるものなり然れども高櫨セメント及びッリヂチット等の混合セメント にに於てはボルトランドセメントとは其の趣を異にしたるものなり即ち特殊の混合セメントにして本邦に於ても 目下立派に工業として成立せるッリデチットの如きものに於てはセメント燒塊に加ふべき花䟖岩の煆燒物つ大 部分は普通のセメント試驗法に於ける不溶解残渣定量法を以てしては殆んど全部不溶解なるを以てッリヂチッ トの不溶解殘渣は花崗岩渥燒物の混合量に應じて普通のポルトランドセメントよりは極めて多量にして時とし

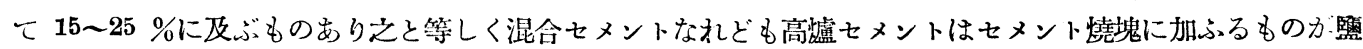

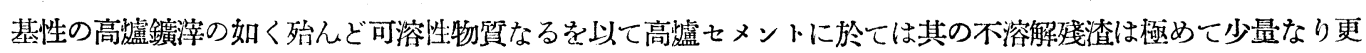
にアルミナセメントに於ては其の原料及で製造法の特殊なる點より考へて不溶解殘渣も亦普通のセメントの夫 れよりは著しく其の趣を異にせり仯外國製セメントの中には普通のポルトランドセメント系のセメントントに 屬しながら其の不溶解殘渣の量は著しく多く成分の翼れるものあり

本報に於ては是等ポルトランドセメント、高㠠セメント、ソリデチット、アルミナセメント等の各種のセメ ントに就て其の不溶解殘渣の成分に就て比較研究したるところを報告せんとするものなり

セメントの不溶解殘渣の量と其の原因

各種のセメントの中ポルトランドセメント系のセメントには不溶解殘洫最も少望にして順調にして合理的な る製造操作の下に製造せられたるポルトランドセメントに於ては普通 $0.3 \sim 0.5 \%$ 出でざる程变のものなるべ し而して此の不溶船殘渣の因つて來るところを考ふるに其の原因は多々もるべしと雖も其の主なるものはセメ

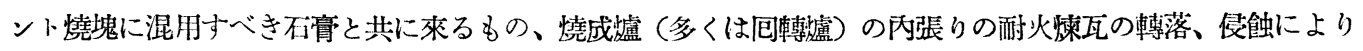
て混入するもの、原粹中の粘士、不灰石等の不純物として長不質のものが燒成盧に於て充分作朋を受けざりし もの、燒成盧の途中に於て調合原料が大塊となり其の中心部が完全に熱變化を受けざりしもの、燒成点、冷却 機等を出でたる後貯藏渾搬中七メント然塊に不純物の混合したるもの、其の他諸種の原因に依るものなるべく

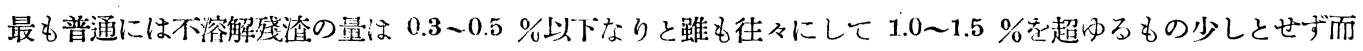
して斯くの如く多量つ不溶解殘渣を含有するポルトランドセメントは前記分如き原因の们机かに依九るものな

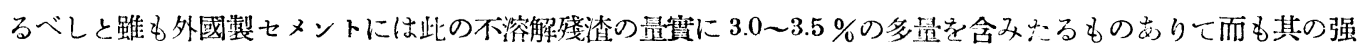




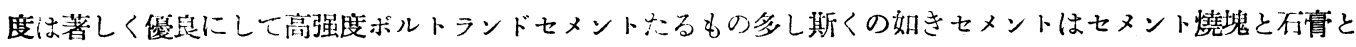
の外に何等かの有用物を混用せるには山らずやと考ふべきものあり或は斯くの如き不溶解殘潜多量なる外國製 セメントの多くは同時に硫酸分の多量なること後節の化學成分表に於て見る如し從つて前述の不溶解殘渣の原 因の第一に考慮したる石謗が特殊なるに起因するものとも考へらる更に或はセメントの硬化促進劑として混用 すべきものに不溶解殘渣たる性質のものを夾雜するが焦めとも考慮せらるべし

普通に行はるるセメントの化學成分の分析表に於ては一般に不溶解殘渣は全く考慮に入れざるか或は全珪酸 分上り不溶解殘渣其盡の量を珪酸と見て控除し其の殘部を可溶性珪酸となし之を以てセメントの水硬率、活動 倸數、其の他の倸數、比率等を算出するもの多し然れども 2 3 \%或は夫れ以上の如く多量の不溶解殘渣を全 部珪酸なりとするは果して妥常なりや否や疑無き能はず之は不溶解殘渣の完全分析をなすことに依りて確めら るべし

高盧セメントはセメント燒魄に加ふるものは全く可溶性の高纑鑛㴖なるべきを以て其の不溶解殘渣の量はポ ルトランドセメントと大美なかるべしソリヂチットの如き特殊混合セメント郎ちセメント燒塊に對し約 20２ $5 \%$ の花崗岩报烓物变混用し此の花崗岩婮燒物の大部分は不溶性なるべきを以て之を混用したるッリヂチット には混用物の約 80〜90 \%は不溶解殘渣となり後筧に揭ぐる如く約 15〜20％の多量なるを常とす

アルミナセメントの如き特殊セメントに就ては其の原料、製造法等の相異に依りて普通ポルトランドセメン

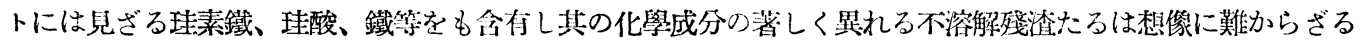
ところなり

ボルトランドセメント采の外國セメントにも此の不溶解殘渣の研究を及ぼし $3.0 〜 3.5 \%$ 多量なるものあり

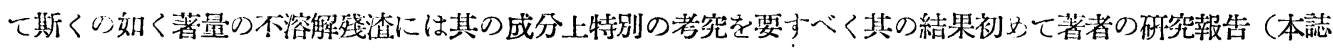
1923，31，942)したるが如き石灰と理酸との化合比率に關する諸種の新係數、比率に就て諭及するを得べし

是等各種のセメントの十數種に就き不溶解殘渣に關する比較呼究結果を次節に報告すべし

\section{セメント試 料}

本報に於ける不溶解璒渣の成分の砸究に供したるセメント試料はポルトランドセメント系セメント7 種、其

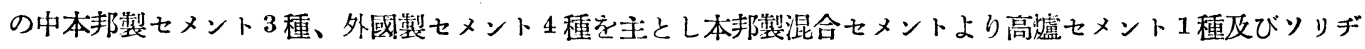
チット 2 種、アルミナセメントとして米國製品なるルムナイト 1 種合計 11 種にして是等セメント試料の一般 化學成分及び物理性に關する比較試驗の結果を表示して本砄究の便に供すべし

\begin{tabular}{|c|c|c|c|c|c|c|c|c|}
\hline & & 第一表 & セメン & 米の化 & & & & \\
\hline $\begin{array}{l}\text { セメント試料 } \\
\text { 番號、種别 }\end{array}$ & $\begin{array}{l}\text { 少淕热诚 } \\
\text { 至 \% }\end{array}$ & $\begin{array}{l}\text { 不濰解 } \\
\text { 殘泚\% }\end{array}$ & 珪酸\% & 勢士\% & $\begin{array}{l}\text { 酸化 } \\
\text { 鐵\% }\end{array}$ & 石灰\% & 苦土\% & $\begin{array}{l}\text { 無水硫 } \\
\text { 酸 } \%\end{array}$ \\
\hline $\begin{array}{c}1 \text { ( ) 本龵製ポルトラント } \\
\text { セメント }\end{array}$ & ド 1.22 & 0.70 & 21.52 & 5.02 & 3.66 & 65.22 & 1.40 & 1.55 \\
\hline 2) II & $1: 30$ & 1.12 & 20.15 & 5.41 & 3.92 & 63.32 & 3.61 & 1.63 \\
\hline 3) I" & 1.33 & 1.21 & 21.58 & 6.00 & 3.60 & 64.01 & 1.47 & 1.74 \\
\hline (4，ヴェロセメント & 2.59 & 2.56 & 20.37 & 6.75 & 2.43 & 63.57 & 1.17 & 2.78 \\
\hline (5) " & 2.27 & 3.78 & 21.16 & 5.88 & 3.45 & 64.28 & 0.91 & 1.76 \\
\hline (6)スペシアルセメント & 1.82 & 3.42 & 21.94 & 5.61 & 2.14 & 62.54 & 2.82 & 2.74 \\
\hline (7)シューパーセメント & 2.98 & 2.60 & 22.50 & 7.06 & 1.50 & 62.99 & 1.12 & 1.13 \\
\hline$(8) 儿$ ム ナ & 2.94 & 2.86 & 8.03 & 38.92 & 6.82 & 38.06 & 0.96 & 0.68 \\
\hline (9)高 爐七メント & 0.74 & 0.78 & 26.53 & 8.24 & 3.14 & 54.86 & 1.34 & 1.28 \\
\hline (10)ソ リヂチット & 1.40 & 17.14 & 31.59 & 5.57 & 3.51 & 53.60 & 1.42 & 1.28 \\
\hline (11) $/ 1$ & 1.67 & 12.80 & 31.51 & 7.26 & 2.66 & 51.59 & 1.70 & 1.70 \\
\hline
\end{tabular}


此の第一表中本邦製ポルトランドセメント（1)、（2、（3）は何れも不溶解残椬の特に多量なるもののみを選 びたるものにして一般には是より少量にして0.2〜0.5\%附近なることは著者の「本邦㢼セメントの試驗報告」(大 日本竿業協會雜誌 $1927,35,384,510,559 ; 1928,36,104,263,44 !, 475 ; 1929,37,39$ 等參照)中の多數の セメントに就て明らかなり外國製セメント(4)、(0)、(6)、(7)は何れも不溶解残渣多く唯英國のフェロクリー トの0.48\%の少量の不溶解殘渣の外の 3 種は本邦洯ボルトランドセメントには未だ類例するものを見ざる多量 の不溶解殘椬を有するものなるを以て茲に本報の硨究資料に供したるものなり(8)ルムナイトの如きアルミナ セメントには不溶解殘渣多く倘酸化チタニウム $1.77 \%$ を合む (9)高盧セメントには酸化マンガン $1.00 \%$ 、硫

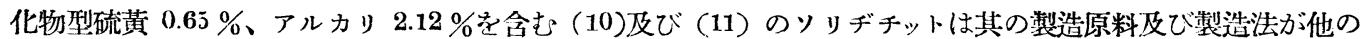
種セメントと異り 20２5％の花崗岩叞燒物の混用の結果多量の不溶解殘渣とアルカリ（10） 1.62％、（11） 1.80 \%を含む此の多量の不溶解殘渣は明らかに花厥岩烺燒物より來れる不英質、長在質より成るらのにしてポ ルトランドセメントの不溶解㙛渣とは自ら差曈を有するものなり

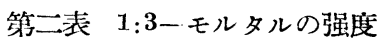

せメント試料

番號、種别

（1）本䑾ボルトランド

(2) セメント

(3) "

(4) ヴェロせメント

(5) "

(6) スペシアルセメント

(7) シューバーセメント

(8) ルムナイト

(9)高爐七メント

(10)ソ リ ヂチット

(11) "

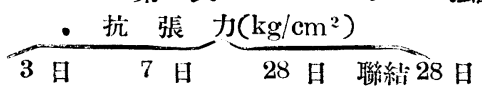

27.7

26.8

2 วั.9

38.1

39.1

31.6

22.5

280

23.7

(2日) 19.5

19.6
29.8

28.9

28.4

38.6

42.6

33.6

28.6

29.0

26.4

25.4

21.3

$31.8 \quad 39.4$

29.7

31.6

37.2

44.8

36.3

33.4

30.3

35.0

31.7

27.5

\section{3}

酎 盟 $\mathrm{s}\left(\mathrm{kg} / \mathrm{cm}^{2}\right)$

第三表 比重、容䅡重、空隐率及び粉未度

セメント試料番號、種别

（1）本利製ボルトランドセメント

(2) "I

(3) II

(4) ヴェロ メント

(5) "

(6) スヘシアルセメント

(7) シューパーセメント

(8) ルムナイト

(9) 高爐セメント

(10)ソリヂテット

(11)"

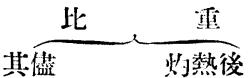

$3.10 \quad 3.22$

$3.13 \quad 3.19$

$3.12 \quad 3.20$

$2.99 \quad 3.09$

$3.01 \quad 3.10$

$3.09 \quad 3.21$

$3.07 \quad 3.18$

$3.02 \quad 3.19$

$3.04 \quad 3.06$

$2.96 \quad 3.06$

$3.05 \quad 3.08$

\section{0}

42.3

41.4

54.3

45.8

41.1

40.6

39.4

- (2日) 166

$31.0 \quad 190$
326

279

317

515

557

514

214

576

273
㱏隙率\% 粉 术 度

$\begin{array}{rr}47.7 & 6.38 \\ 46.4 & 3.68 \\ 46.1 & 2.14 \\ 51.2 & 1.56 \\ 52.6 & 0.60 \\ 49.9 & 1.44 \\ 46.8 & 2.88 \\ 45.0 & 3.06 \\ 50.6 & 3.10 \\ 45.9 & 15.31 \\ 48.5 & 8.25\end{array}$

是等第二表及び第三表に就て見る如く（4）及び（5)のヴェロセメントは高級セメントたるに充分なる强度を 有し粉末度は高く容積重及び比重は共に小なるを以て空吵率は最も大なり（6)スペシアルセメントも之に次ぐ 高强度セメントにして本邦製品 (1)、(2)、(3)はポルトランドセメントとしては之に次ぎ（7)シューパーセメ ント最も劣るものなり（8)ルムナイトの如きアルミナセメントが短期强度の最も大なるは當然なれども既に 7 日にて（5)ヴェロセメントに劣り 28 日以後は（4)、(5)、(6)等のポルトランドセメント系の高級セメントに 
劣ることは最も注日すべき點なり混合セメントは何れも比重小にして强度も亦小なれども最近の製品に於ては 高盧セメントはポルトランドセメントを倰ぐに至りソリヂチッ:トに於ても著者の別報「混合ポルトランドセメ ントの研究」(本誌 1929，32,313 以下參照)に報告する如人極めて優秀なるものを得ることに成功しつડあり 妶に選出したる本邦製ポルトランドセメント（1）、（2）、(3）が第一表に見る如く特に不溶解殘渣の多量な るもののみなるは次第に述べもとする如くセメント中の不溶解殘椬の完全分析を行ふべき充分の量を集むるは 䊉めて煩雜なる操作を反潭するを要するが墨め不溶解殘渣の含有量の比較的多量なる試料を必要としたるが爲 めなり

セメントの不浴解殘渣の蒐集

既に第一表に示したるセメント試料の不溶解殘洫の如何なる成分より成るかを究めんが瓷めには是非とも此 の不溶解殘椬を相當の量に菟集して之を完全分析試驗に附すべきなり此の故を以てセメント試料より其の不溶 解残渣として僅かに $1 \%$ 前後のものを菟集するには樌めて煩雜厄介なる操作を反覆せざるべからず郎ちセメン トの一般化學分析試驗に於ける不溶解殘渣の定量に於けると同樣にセメントの1〜2gの少量をビーカー中にて 少量の水にて泥狀となし之に濃廐酸 1 谷と水 2 容との割合の監酸を加へて湯浴上にて加熱溶解せしめたるもの を水を以て數倍に稀め滤過し糊䣋の可溶性珪酸は炭酸曹澾の 10 \%溶液を以て加熟して完全に溶解せしめたる

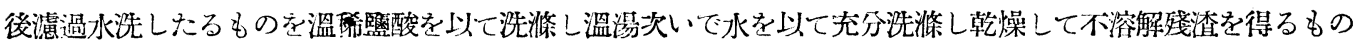
なり此の方法をセメント約 50〜 $100 \mathrm{~g}$ (不溶解殘渣の多少に應じて異る)を數十佨に分ちて反覆して行ひ甚だし きは 1 個月以上の時日を費して漸く完全分析を行ふに足る不溶解殘渣の量さ得たるものあり若し之を每包セメ

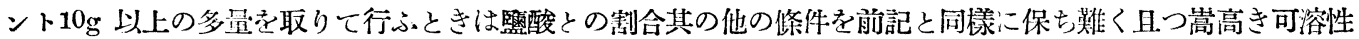
珪酸の多量を取り扱ふ際此の可溶性珪酸の一部が完全に炭酸曹澾液に溶解せられ盡さずして操作中不溶解性の

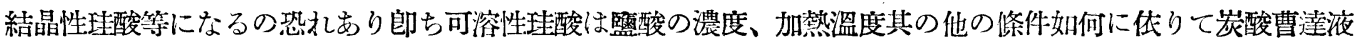
に對する溶解性を著しく異ならしむ斯くてはセメントに元來含有せられたる不溶解战湓の成分を研究せんとす る本報の目的に對して最も㴍ふべきものなり從つて前記の如く㰒く少量宛つセメントに就き一般の不溶解殘盉 の定量の場合と闰樣の操作を數十包反覆するの煩雜を忍びて溸く不溶解殘椬を蒐集したるものなり剆ち此の不 溶解殘渣の蒐集には苴に预想以上の日數と手數とを要して漸く完全分析に゙附し得べき $0.7 〜 1 .(\mathrm{g}$ 前後の不溶解 殘渣試料を集むるを得なるものなり

\section{不溶解殘渣の試料の成分}

前記の如き煩雜なる方法を以て丹念に蒐集したるセメント試料の不溶解殘渣を試料とし其の化學成分を究め んが鴬め蒐集したる試料は一度之を $105 〜 110^{\circ} \mathrm{C}$ に乾燥して何れも白色或は稍灰白色乃至黄褐色を呈せる微粉 末となれり但し（8）ルムナイトの不溶解殘椬は是とは異り殆んど灰黑色をなせるは其の理由としてアルミナセ メントが電氣爐製造法に依るを以て珪素鐵、酸化鐵等を含めるものなるべく是等は前記の稀䁬酸にて加溫する のみにては不溶解殘渣つ部に殘るべく其䉆めの灰黑色なるべし

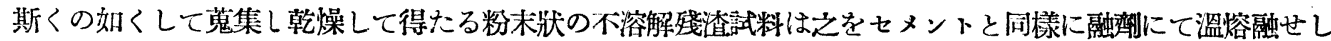
むる方法にて完全分析に附し得べく先づ白金坩堝にて灼熱して其の灼熱減量を見次に融劑を加へセメントの普 通分析法に準じて愹融物より完全分析をなしたり硫酸分は前記の如き不溶解殘渣の蒐集操作の結果に於ては不 溶解つ临殘ることは确んど無かるべく從つて硫酸分は存在せざるべし佾ルムナイトの不溶解殘渣中には酸化于 
タンを含有すること無しとせざれどもとを酸化鐵より分離せずして酸化鐵に加へたり

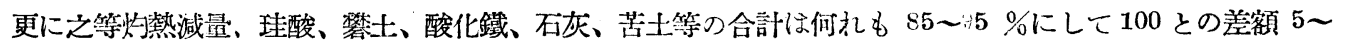
15\%の大部分はアルカリなるべく之は直接定量を行はずして次の第四表の如く差額の価之を示したり

第四表 セメント試料の不溶解殘渣の化學成分

セメント試料番號、種别 灼熱減量\%

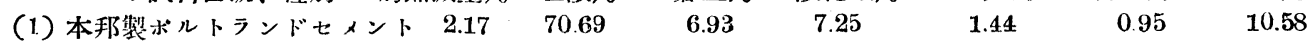

(3) "

$2.15 \quad 76.48$

$7.79 \quad 2.78$

0.67

1.16

9.37

(4) ヴェロヒメント

$3.22 \quad 77.27$

5.82

4.13

1.02

057

7.97

(5) "

$4.68 \quad 80.08$

(6) スペシアルセメント

$4.06 \quad 80.89$

4.93

1.36

1.03

1.91

7.01

(7) シューハーセメント

2.33

81.46

3.68

5.40

81.04

(8)ルムナイト

2.97

61.06

(9) 高爐七メント

7.21

74.71

1.01

0.96

0.98

750

(10)ソリヂテット

1.55

$75.2 \check{5}$

(11)"

1.32

73.74

5.19

7.23

23.41

3.68

8.04

7.70

2.01

痕跡

3.50

2.32

3.16

8.49
0.97

0.26

2.25

0.29

2.25

1.53

0.70

7.34

$0.58 \quad 549$

$1.44 \quad 4.75$

$0.76 \quad 11.03$

$1.61 \quad 8.10$

0.626 .60

此の第四表の結果に就て見るにセメント中の不溶解殘洫の主成分は珪酸、攀土及びアルカリにして從つて不 溶解残渣の大部分は不溶解性の石英質(珪酸)と長不質 (アルカリ珪酸攀土) とより成るものと考へらる故に別 報「セメントの聯結硬化の强度と化學成分」第二報(本誌 1928，31，913) 及び「セメントの水硬成分に關する 新比率に就て」第二埌（本誌 $1929 ， 32 ， 236 ， 243$ )等に述べたる如くセメント小の全珪酸分より不溶解殘䄳の 全量を理酸と見て控除するは不賞なるべきを以て第匹表に見る如く琲酸 75〜80\% 之を灼熱物に換算す扎ば

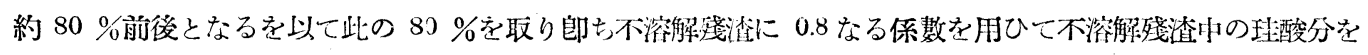
算出し全珪酸より控除してセメントかの可溶性珪酸㿼を生成すべき理酸と考へ此の數佔を使用して不灰珪酸化

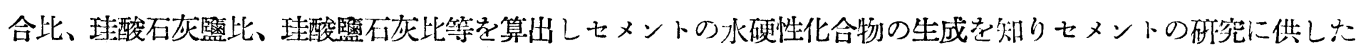
り是等の新比率を本邦彆セメントの多數に適用してとを批湖したるものは別報「セメントの聯結硬化の强度と 化學成分」及び「セメントの水硬成分に關する䉼比率に就て」(前出) 及び大日本筧業永會雜誌 $(1929,37,87$ 以下）に就て報告しつ১あり是等の新比率はポルトランドセメント系のセメントに就週用し得るものにして アルミナセメントの如き別種のセメント或は高盧セメント及びッリヂチットの如き混合セメントに就ては全く 特殊の混合セメントなる篇め是等の新比率定適用し䧼きものなるは勿諭なり

ヴェロセメント、スペシアルセメント及びシューパーセメント等の外國製ポルトランドセメントに多量含有 せらるる不溶解残查の成分に就ては第四表に見る如く本邦製ポルトランドセメント（1）、(2)、(3)の不溶解残渣 よりは珪酸分稍多量なりと雖も大體に於て殆んど大差無し從つて是等外國製セメント小の不溶解殘渣も亦前に 述べたる如くセメント製造操作中諸種の原因を以て混入し來れるものなるべく特に混合劑等として混じたるも のにはあらざるべし唯（4）ヴェロセメント、(6)スペシアルセメント等に硫酸分の $2.5 \%$ 以上の如く多量なる と此の不溶解残渣の多量なるとを併せ考ふる時はセメント燒塊の粉猝に際して加ふべき石育の不純物として粘 土質、長石質等の混入物が不溶解殘渣の多量となれるものの如く推察せらる即ち天然の石高にして硫酸カルシ ウム分少く不純物として粘土質、長石質或は石英質等の脈石物の混入多き石望に於ては石高をセメント燒塊に 加ふる量 3〜1\%より多くして假に5〜6\%も使用し硫酸カルシウム分以外の不純物 20〜25\%の如き不純物 ある石骨なりとすれば（4)、(6) セメシトの如く硫酸分が 25 3\%なるが䉆めには此の不純物より來る不溶解 殘渣のみにても忽ち 1.0 1.5\%にも昇ることは容易に想像し得べし從つて不溶解殘椬及び硫酸分が此の石高以 
外他の原因より混入し來るものを加られしば（4)及び（6)セメントの如く不溶解残渣 3.0 - $3.5 \%$ 、硫酸分 2.0 $2.5 \%$ \%超過するが如きことは特に稀行とするに足らざるべしと信ず

總括

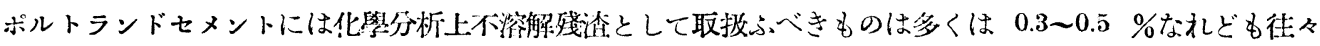
にして $1.0 \%$ 以上洔には $2.0 \%$ 越え外國製セメントの或るものには $3.5 \%$ 上の如きものあり是等の不浴觨 婑渣の全部を珪酸と見做して全珪酸分より控除して化合珪酸分と寸るは不罍なるべく著者が別報を以てボルト ランドセメントに就て新に提出したるセメントの主要水硬性化合物に關する比䆻として石灰珪酸化合比、珪酸

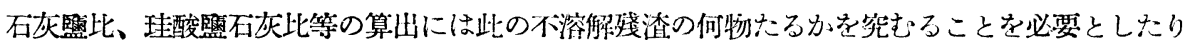

更にセメントの不溶解残渣が如何なる原因に依りて混入し來るものなるかを究めんがためには其の全分析絬 果に俟つべきもの多きを以て本邦セメントにして不溶解殘渣比較的多量なるもの 3 種、外國製セメントにして 不溶解殘渣更に多きもの 4 種を取り更に是等ポルトランドセメント以外の特殊セメントとしてアルミナセメン

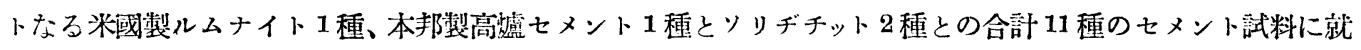

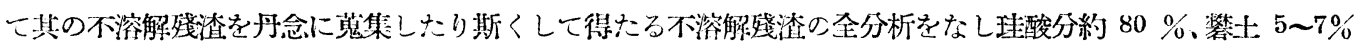
酸化鐵 2〜5\%、アルカリ約 7〜9 \%を主とするものなるを確めたり從つて此の不溶解殘渣は石英筫、長石筫 等を主とし粘土質もセメント燒塊の粉稡機中の溫度(約 150 ～ $170^{\circ} \mathrm{C}$ )のみにては不溶解性のま〉なるべく是等: 不溶解殘渣含有の原因として舉ぐべきもの數多も机ども不育中に含有せらるる不純物に原因すべしと考ふべき もの多かるべし硫酸分の多量なる外卧セメントのヴェロセメント及でスペシアルセメントに於て不溶解殘渣の 多量なるは之を確登するものの彻し

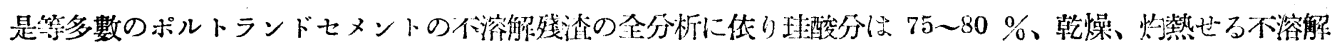

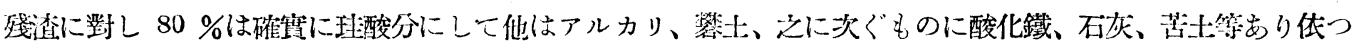

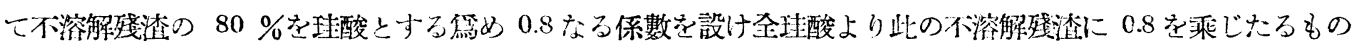
を控除して可溶性にして石灰と結令寸べき王酸分艺求めて以てボルトランドセメントの主要水硬性化合物に關 寸る新比率、係數の算出の基礎となしそにセメント中の遊離石灰の最も正確なる定量洼を併肞して本邦製ポル

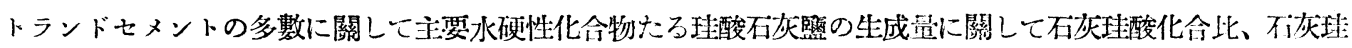

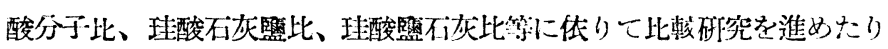

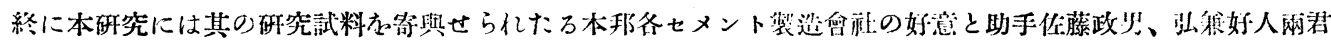

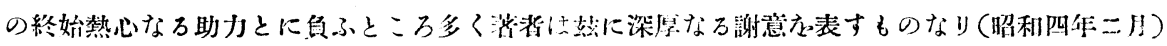

